\title{
A Critical Analysis on Law Governing Parole in India
}

\author{
Dr. K. Sangeetha*
}

Assistant Professor, Department of Environmental Law, School of Excellence in Law, The Tamil Nadu Dr. Ambedkar Law University, 5, Dr. D.G.S. Dinakaran Salai, State Bank of India Colony, Raja Annamalai Puram, Chennai, Tamil Nadu 600028, India

DOI: $10.36348 /$ SIJLCJ.2019.v02i09.001 $\quad$ | Received: 26.08.2019| Accepted: 16.09.2019| Published: 29.09 .2019

*Corresponding author: Dr. K. Sangeetha

\section{Abstract}

Historically 'parole' is a concept known to military law and denotes release of a prisoner of war on promise to return. Parole has become an integral part of the English and American systems of criminal justice intertwined with the evolution of changing attitudes of the society towards crime and criminals. In those Countries, parole is taken as an act of grace and not as a matter of right and the convict prisoner may be released on condition that he abides by the promise. It is a provisional release from confinement but is deemed to be a part of the imprisonment. Release on parole is a wing of the reformative process and is expected to provide opportunity status of the prisoner. Parole system means the system of releasing prisoners in jail on parole, by suspension of their sentences in accordance with the rules for the time being in force. Regular Parole is allowed for a maximum period of one month, except in special circumstances, to convicts who have served at least one year in prison. Parole is granted on certain grounds such as:-

- Serious Illness of a family member

- Accident or Death of a family member

- Marriage of a member of the family

- Delivery of Child by wife of the convict

- Serious damage to life or property of the family of convict by natural calamities.

Certain categories of convicts or prisoners are not eligible for being released on parole. Prisoners involved in offences against the State, or threats to National Security, Terrorism, Non-Citizens of India etc. People convicted of murder and rape of children or multiple murders etc. are also exempted except at the discretion of the granting authority [1]. If an application is made by the prisoner for granting parole is not released on parole, then the prisoner or convict can file a writ petition through a Lawyer or an Advocate in the Hon'ble High Court seeking relief of parole. In some cases High Courts have granted parole to convicts seeking distance education or correspondence study to appear for exams and also if the prisoner wants to get married or register his marriage during the period of undergoing conviction. Undoubtedly, parole and furlough are parts of the penal and prison system for humanising prison administration but the two have different purposes. Furlough is a matter of right but parole is not. Furlough is to be granted to the prisoner periodically irrespective of any particular reason merely to enable him to retain family and social ties and avoid ill-effects of continuous prison life. The period of furlough is treated as remission of sentence. Parole, on the other hand, is not a matter of right and may be denied to a prisoner even when he makes out sufficient case for release on parole if the competent authority is satisfied on valid grounds that release of a prisoner on parole would be against the interest of society or the prison administration. It is treated as a period spent in prison. But as against this, the period spent on parole is not counted as remission of sentence. Since the furlough is granted for no particular reason, it can be denied in the interest of society, whereas parole is to be granted only on sufficient cause being shown. Thus, it could not be contended that a prisoner released on parole and surrendering later, is disqualified for furlough. His application for release on furlough has to be considered on merits and cannot be rejected at the threshold. Referring to the provisions of Section 59 of the Prisons Act (9 of 1894) and Rules 4 and 6 of the Prison (Bombay Furlough and Parole) Rules, 1959, the Supreme Court once again brought out the distinction between furlough and parole in State of Maharashtra and another v. Suresh Pandurang Darvekar [2]. The Court in this case held that underlying object of the rules relating to 'parole' and 'furlough' are mentioned in the All India Jail Committee's Report and the Model Prison Manual. These two have two different purposes. It is not necessary to state reasons

1As per the standard procedure after an inmate seeks parole, Jail Authority (Superintendent of the Jail) asks for a report from the respective police station that had made the arrest. The report, with all other papers like medical report (in case of illness being reason for parole), recommendation of the Superintendent of Jail are then sent to the Deputy Secretary, Home (General), State Government or Inspector General of Prisons (I.G. - Prisons) which decides on the application.

2 Criminal Appeal 421 of 2006. SLP (Crl) No. 417 of 2006. Criminal Bench Justice Arijit Pasayat and S.H. Kapadia. 
while releasing the prisoner on furlough but in case of parole, reasons have to be indicated. Again, release on furlough cannot be said to be an absolute right of the prisoner. Parole is essentially an executive function and instances of release of detenues on parole were literally unknown until this Court and some of the High Courts in India in recent years made orders of release on parole on humanitarian considerations. This Article would explain all the above mentioned issues and how to improve the Law available in India.

Keywords: Historically ‘parole', Law Governing Parole.

Copyright @ 2019: This is an open-access article distributed under the terms of the Creative Commons Attribution license which permits unrestricted use, distribution, and reproduction in any medium for non-commercial use (NonCommercial, or CC-BY-NC) provided the original author and source are credited.

\section{INTRODUCTION}

Historically 'parole' is a concept known to Military Law and denotes release of a prisoner of War on promise to return. Parole has become an integral part of the English and American systems of Criminal Justice intertwined with the evolution of changing attitudes of the Society towards Crime and Criminals. In those Countries, parole is taken as an act of grace and not as a matter of right and the convict prisoner may be released on condition that he abides by the promise. It is a provisional release from confinement but is deemed to be a part of the imprisonment. Release on parole is a wing of the reformative process and is expected to provide opportunity status of the prisoner.

There are many devices adopted by the prison administration to ease tension in the prison. One of the most important devices for reducing pressure on prison is the selective release of prisoners on parole. It is a treatment programme. It seeks to protect society and assist the prisoner in readjusting himself to a normal free life in the community. The offender after serving part of a term in a correctional institution is conditionally released under supervision and treatment. It does not waste the sentence imposed, but merely suspends the execution of the penalty and temporarily release the convict from prison.

A Parole in Criminal Law is the release of a convict from imprisonment upon certain conditions to be observed by him. It is a release from prison after part of the sentence has been served, the prisoner still remaining in custody and under stated conditions until discharged and liable to return to the institution for violation of any of these conditions. Parole may be described as a method of selectively and conditionally releasing offenders from goal before the expiration of their sentences for the purpose of assisting and controlling them during the period of transition from the prison environment to the community [3].

Professor Gillin has defined parole as the release from a penal or reformatory institution of an offender who remains under the control of correctional authorities, in an attempt to find out

3 David Biles (Ed.) "Crime and Justice in Australia", (1977) p.126. See also J.E. Hall Williams, "The English Penal System in Transition", (1970), pp. 184- 200. whether he is fit to live in the free society without supervision. The layman and most courts look upon parole as a gift to the convict, an act of leniency on the part of the executive, frequently given as a reward for good behaviour in Prison. Strictly speaking parole is a privilege and no prisoner is entitled to it as a rnatter of right [4]

The significance of parole lies in the fact that it enables the prisoner a free social life, yet retaining some effective control over him. Every prisoner is kept under careful exarninat ion and one who reacts favourably to the disciplined life of the institution and shows potentiality for correction in his attitudes is allowed considerable latitude and finally released to join free society conditionally at specified periods [4]. Thus parole is essentially an individualised method of treatment and envisages a final stage of adjustment of the incarcerated prisoner to the community.

It is difficult to define parole in terms of a single precise concept. It is an integral part of the total correctional process. In a sense parole is a method of selectively releasing offenders from institutions, under supervision in the community, whereby the community is afforded continuing protection while the offender is making his adjustment and beginning his contribution to society [5].

In India, there are no statutory provisions dealing with the question of grant of parole. The Code of Criminal Procedure does not contain any provision for grant of parole. By administrative instructions, however, rules have been framed in various States, regulating the grant of parole. In our Country, the action for grant of parole is generally speaking, an administrative action. According to section 2(p) of the Delhi Prisons Act, 2000 'Parole system' means the system of releasing prisoners from prison on parole by suspension of their sentences in accordance with the rules. Since the term 'Parole' has not been defined by the legislature anywhere, its meaning can be understood and extracted from the interpretation given in various dictionaries.

According to the Law Lexicon, 'A parole', is a form of conditional pardon, by which the convict is

4 Charles L. Newrnan, "Source Book on Parole and Pardons", (1970), p.73.

5 N.V.Paranjape, "Criminology and Administration of Criminal Justice”, (1970), p.177. 
released before the expiration of his term, to remain subject during the remainder thereof, to supervision by the public authority and to return to imprisonment on violation of the condition of the parole.

According to Words and Phrases, 'Parole' ameliorates punishment by permitting convict to serve sentence outside of prison walls, but parole does not interrupt sentence. Parole has been defined in Black's Law Dictionary, as 'release from jail, prison or other confinement after actually serving part of the sentence'. Further Sunil Fulchand Shah's case [6] the Apex Court describes "parole" as a form of "temporary release" from custody, which does not suspend the sentence or the period of detention, but provides conditional release from custody and changes the mode of undergoing the sentence.

\section{HISTORY OF PAROLE}

The history of parole has been discussed at length by the Hon'ble Supreme Court in Poonam Lata's case where it is mentioned that "Historically 'parole' is a concept known to military law and denotes release of a prisoner of war on promise to return. As a consequence of the introduction of parole into the penal system, all fixed-term sentences of imprisonment of above 18 months are subject to release on licence, that is, parole after a one third of the period of sentence has been served. In those Countries, parole is taken as an act of grace and not as a matter of right and the convict prisoner may be released on condition that he abides by the promise.

It is a provisional release from confinement but is deemed to be a part of the imprisonment. Release on parole is a wing of the reformative process and is expected to provide opportunity to the prisoner to transform himself into a useful citizen. Parole is thus a grant of partial liberty or lessening of restrictions to a convict prisoner, but release on parole does not change the status of the prisoner. Rules are framed providing supervision by parole authorities of the convicts released on parole and in case of failure to perform the promise, the convict released on parole is directed to surrender to custody."

\section{OBJECTIVE OF PAROLE}

In the absence of any specific provision in the Code of Criminal procedure regarding parole; judgments of the Hon'ble Supreme Court, various High Courts as well as the rules framed in various States, regulating the grant of parole has led to the development of parole system in India. Parole has now become an integral part of Criminal Justice System in India.
The Division Bench of the Hon'ble High Court of Delhi in Shakuntala Devi v. State [7] has emphasized that under our Constitution, deprivation of personal liberty as penal policy is purposive because the imprisonment of the criminal is sanctioned as a measure of social defence and individual rehabilitation.

The focus of interest in penology is the individual and the goal is salvaging him for Society. Time to time the Apex Court has held that all aspects of Criminal justice fall under the umbrella of Articles 14, 19 and 21 of the Constitution. Further the Apex Court has sought to humanize prison administration to some extent through its various pronouncements and it has also laid great emphasis on the right of a prisoner to the integrity of his physical person and mental personality. The Apex Court views sentencing as a process of reshaping a person who has deteriorated into criminality and the modern community has a primary stake in the rehabilitation of the offender as a measure of social defence.

Further in Inder Singh v. State [8] the Apex Court has held that if the behaviour of these two prisoners shows responsibility and trustworthiness, liberal though cautious, parole will be allowed to them so that their family ties may be maintained and inner tensions may not further build up. After every period of one year, they should be enlarged on parole for two months......' In view of the aforesaid, it is evident that the main objective and purpose of granting parole is to the rehabilitate the prisoners and to provide them an opportunity to reform themselves into a better human being, to allow them to develop a positive attitude and interest in life and also to provide them with an opportunity to maintain their social ties.

\section{KINDS OF PAROLE}

Custody Parole and Regular Parole are the two kinds of parole to which a convict is eligible. Custody Parole can be granted in emergent situations and circumstance only such as death of a family member, marriage of family member, serious illness of family member or in any other emergent circumstances. During the Custody Parole, the prisoner has to be escorted to the place of visit and return there from ensuring the safe custody of the prisoner. Such prisoner would be deemed to be in prison for the said period and the same would also be treated as period spent in prison.

In all other situations, it is open to the Government to consider applications for Regular Parole. Some of the grounds on which the applications of the prisoner may be entertained are:

1. Serious illness of a family member 
2. Critical conditions in the family on account of accident or death of a family member

3. Marriage of any member of the family of the convict

4. Delivery of a child by the wife of the convict if there is no other family member to take care of the spouse at home

5. Serious damage to life or property of the family of the convict including damage caused by natural calamities

6. To maintain family and social ties

7. To pursue the filing of Special Leave Petition before the Supreme Court of India again a judgment delivered by the High Court convicting or upholding the conviction, as the case may be

\section{DIFFERENCE BETWEEN PAROLE AND BAIL}

Parole and Bail are viewed by many people as the same, however there exists difference between Parole and Bail and both have different connotations in Law. Bail is well understood in Criminal Jurisprudence and Chapter XXXIII of the Code of Criminal Procedure contains provisions relating to grant of Bail. Sections 436, 437, 438 and 439 of the Code of Criminal Procedure respectively specify the power of the Courts to grant bail. Section 436 provides for bail in bailable offences, section 437 provides as to when bail may be taken in case of non-bailable offences, section 438 talks about direction to grant of bail to person apprehending arrest and 439 stipulates about special power of High Court and Court of Sessions to grant Bail. The effect of granting bail is to release the accused from internment though the Court would still retain constructive control over him through the sureties. In case the accused is released on his own bond such constructive control could still be exercised through the conditions of the bond secured from him.

The Apex Court in Sunil Fulchand Shah's case (Supra) while discussing about bail has held that the effect of granting bail is not to set the defendant (accused) at liberty but to release him from the custody of law and to entrust him to the custody of his sureties who are bound to produce him to appear at his trial at a specified time and place. The sureties may seize their principal at any time and may discharge themselves by handing him over to the custody of law and he will then be imprisoned.

The Hon'ble Supreme Court in State of Haryana v. Mohinder Singh while distinguishing bail from parole has mentioned that Parole is a provisional release from confinement but is deemed to be a part of the imprisonment. Release on parole is a wing of the reformative process and is expected to provide opportunity to the prisoner to transform himself into a useful citizen. Parole is thus a grant of partial liberty or lessening of restrictions to a convict prisoner, but release on parole does not change the status of the prisoner. Rules are framed providing supervision by parole authorities of the convicts released on parole and in case of failure to perform the promise, the convict released on parole is directed to surrender to custody.

\section{POWER TO GRANT PAROLE}

The power to grant Parole is essentially the function of the executive and to consider the request made by the prisoner for his release on parole is the prerogative of the executive only. Rules have been framed in every State regulating the grant of parole. Every prisoner before his entitlement for his release on parole has to meet certain eligibility criteria.

As per the Parole/Furlough Guidelines 2010 (Supra) in order to be eligible for release on parole (i) a convict must have served atleast one year in prison excluding any period covered by remission (ii) the conduct in prison must have been uniformly good (iii) during the period of parole, if granted earlier, the convict should not have committed any crime(iv) the convict should not have violated any terms and conditions of the parole granted previously (v) a minimum of six months ought to have elapsed from the date of termination of the earlier parole.

However, under the below mentioned circumstances, the prisoners/convicts would not be eligible for being released on parole: Convicts whose release on parole is considered dangerous or a threat to national security or there exists any other reasonable ground such as a pending investigation in a case involving serious crime; (ii) Prisoners who have been involved in crimes and offences against the State, like sedition or who have been found to be instigating serious violation of prison discipline;(iii) Prisoners who have escaped from jail;(iv)The prisoner is not a citizen of India.

Further in the following cases, parole would ordinarily be not granted except, if in the discretion of the competent authority special circumstances exist for grant of parole;

- If the prisoner is convicted of murder after rape;

- If the prisoner is convicted for murder and rape of children;

- If prisoner is convicted for multiple murders.

The period of release on parole shall not, ordinarily, exceed one month at a time except in special circumstances to be mentioned in the order granting parole. The Government shall decide the period of release on the merits of each case, for reasons to be specified in the order granting parole.

\section{WRIT JURISDICTION AND PAROLE}

No doubt the grant of parole is essentially an executive function, however, if the Court finds that any Government action in rejecting the grant of parole to a 
prisoner has the effect of suffocating the Article 14 or 21 of the Constitution, then the Court has all the powers to restore the rule of law and respect the residuary fundamental rights of an aggrieved prisoner.

It has been held by the Hon'ble High Court of Delhi in Sharda Jain's case [9] that the grant of parole being essentially an executive function, it is for the Government to consider the request made by the convict for the purpose and to pass an appropriate order on it. If however, the order passed by the Government declining parole is based upon irrelevant ground or extraneous considerations or is otherwise wholly unsustainable being an order which no reasonable person could, in the facts and circumstances of the case have passed or is totally perverse, it is open to the Court, in exercise of its powers under Article 226 of the Constitution to set aside an order and direct the release of a convict on parole.

The Apex Court in Poonam Lata v Wadhawa and others [10] case has also held that 'On the principle that exercise of administrative jurisdiction is open to judicial review by the Superior Court, the High Court under Article 226 or this Court under Article 32 may be called upon in a suitable case to examine the legality and propriety of the Governmental action. There is no scope for entertaining an application for parole by the court straightway'.

In Sunil Fulchand Shah v Union of India [11] case, the Constitutional bench of the Apex Court has held that, 'the bar of judicial intervention to direct temporary release of a detenue would not, however, affect the jurisdiction of the High Court's under Article 226 of the Constitution or of this Court under Article 32, 136 or 142 of the Constitution to direct the temporary release of the detenue, where request of the detenue to be released on parole for a specified reason and/or for a specified period, has been, in the opinion of the Court, unjustifiably refused or where in the interest of justice such an order of temporary release is required to be made. That jurisdiction, however, has to be sparingly exercised by the Court and even when it is exercised, it is appropriate that the Court leave it to the administrative or jail authorities to prescribe the conditions and terms on which parole is to be availed of by the detenue'.

Parole was introduced as a way to encourage responsible behavior in rehabilitating the prisoners and at the same time to provide them an opportunity to reform themselves into a better human being and also to provide them with an opportunity to maintain their social ties. Some of the major concepts that underlie the parole system include the reduction of jail term after

9 (2010) 167 DLT 655.

10 AIR 1975 SC 606.

11 2000(1)SCR 945. good and responsible behavior in prison and to allow the prisoners to develop a positive attitude, self confidence and interest in life.

Power to grant parole is purely an administrative decision, however, the executive must exercise the discretion vested in it judiciously and not arbitrarily and always keeping in mind the objectives of the parole and also taking into consideration that regardless of the crime a man may commit, he still is a human being and has human feelings also. Therefore the nature and length of sentence or the magnitude of the crime committed by the prisoner are not relevant for the purpose of grant of parole

\section{Practice and Procedure of Granting Parole}

Parole is granted to a prisoner in certain Special circumstances. It is subjected to certain limitations and conditions imposed by the releasing authority. The underlying idea behind the concept of parole is the realisation by the society that the man behind the bars is still the member of his family and society, that he has the same human wants, urges, duties and obligations [12].

The rehabilitative purpose of sentencing would be promoted by permitting him to fulfill those basic human needs and social duties by occasionally permitting him to live for short periods in his home as well as in the community where he has his roots. There are certain recognised circumstances under which parole is usually granted. If a member of the prisoner's family dies or become seriously ill, or the marriage of his son or daughter is to be celebrated, the authority used to release the prisoner [13].

Certain categories of convicts or prisoners are not eligible for being released on parole. Prisoners involved in offences against the State, or threats to National Security, Terrorism, Non-Citizens of India etc. People convicted of murder and rape of children or multiple murders etc. are also exempted except at the discretion of the granting authority [14].

12 The eminent Criminologist Sutherland considers parole as the liberation of an inmate from prison or a correctional institution on conditions, with restoration of the original penalty if those conditions of liberation are violated. Sutherland and Cressy, "Principles of Criminology", (6thEdn.), p.575.

13 In Hiralal Mallick v. State, A.I.R. 1977 S.C. 2236, the court was of view that periodic parole was a desirable measure.

14 As per the standard procedure after an inmate seeks parole, Jail Authority (Superintendent of the Jail) asks for a report from the respective police station that had 
If an application is made by the prisoner for granting parole is not released on parole, then the prisoner or convict can file a writ petition through a Lawyer or an Advocate in the Hon'ble High Court seeking relief of parole. In some cases High Courts have granted parole to convicts seeking distance education or correspondence study to appear for exams and also if the prisoner wants to get married or register his marriage during the period of undergoing conviction.

Undoubtedly, parole and furlough are parts of the penal and prison system for humanising prison administration but the two have different purposes. Furlough is a matter of right but parole is not. Furlough is to be granted to the prisoner periodically irrespective of any particular reason merely to enable him to retain family and social ties and avoid ill-effects of continuous prison life.

The period of furlough is treated as remission of sentence. Parole, on the other hand, is not a matter of right and may be denied to a prisoner even when he makes out sufficient case for release on parole if the competent authority is satisfied on valid grounds that release of a prisoner on parole would be against the interest of society or the prison administration. It is treated as a period spent in prison. But as against this, the period spent on parole is not counted as remission of sentence. Since the furlough is granted for no particular reason, it can be denied in the interest of society, whereas parole is to be granted only on sufficient cause being shown.

Thus, it could not be contended that a prisoner released on parole and surrendering later, is disqualified for furlough. His application for release on furlough has to be considered on merits and cannot be rejected at the threshold. Referring to the provisions of Section 59 of the Prisons Act (9 of 1894) and Rules 4 and 6 of the Prison (Bombay Furlough and Parole) Rules, 1959, the Supreme Court once again brought out the distinction between furlough and parole in State of Maharashtra and another v. Suresh Pandurang Darvekar [15].

The Court in this case held that underlying object of the rules relating to 'parole' and 'furlough' are mentioned in the All India Jail Committee's Report and

made the arrest. The report, with all other papers like medical report (in case of illness being reason for parole), recommendation of the Superintendent of Jail are then sent to the Deputy Secretary, Home (General), State Government or Inspector General of Prisons (I.G. - Prisons) which decides on the application.

15 Criminal Appeal 421 of 2006. SLP (Crl) No. 417 of 2006. Criminal Bench Justice Arijit Pasayat and S.H. Kapadia. the Model Prison Manual. These two have two different purposes. It is not necessary to state reasons while releasing the prisoner on furlough but in case of parole, reasons have to be indicated. Again, release on furlough cannot be said to be an absolute right of the prisoner. Parole is essentially an executive function and instances of release of detenues on parole were literally unknown until this Court and some of the High Courts in India in recent years made orders of release on parole on humanitarian considerations.

The prisoners are temporarily released on parole to enable them to carry on agricultural operations. The release on parole for whatever reason shall, however, be subject to the discretion of authorities. These various grounds indicate that the law on the subject of parole recognises that incarceration should not lead to the prisoner's total alienation from the family or community and ensures his continuing participation. The procedure adopted for releasing a person under parole consists of two steps selection and supervision. A properly constituted parole committee has to select carefully those inmates who are to be set free on parole. They assess both the eligibility and the suitability of the inmates to be released on parole. The eligibility is decided by the statutes dealing with the parole of inmates.

The Authorities weigh the positive and negative factors in each case and on the basis of that parole is granted. It involves a balancing of the interests of the prisoner and those of the public. Factors considered relevant in deciding whether the offender should be released may include such matters as the likelihood of the offender committing further offences while on parole; the offender response to prison treatment: the offender's needs and especially the nature and gravity of the offence for which he was imprisoned.

Generally before granting parole, the authorities take into consideration the reports from social agencies, pre-parole investigation reports, comments by the judge or prosecuting counsel, the studies and observations made by the trained prison staff during the inmate's stay in the prison. These studies may include psychiatric and psychological reports, extensive social history, intensive pre-parole investigation reports prepared by the field officers, education in prison, his conduct, attitude and many other things relevant for the purpose.

In India there exists no system to prepare all these elaborate reports as done in some Western Countries. Here the authorities depend upon only those factors and reports which the penal system is able to provide. This situation calls for change. Better and sophisticated methods should be introduced for evaluating the 
inmates' eligibility before parole is granted. The treatment meted out to the prisoners since their entry into the prison should be tailored to suit their rehabilitative needs.

They should be mentally prepared to get into the mainstream after a period of detention. Parole should be decided in such a manner that the parolee may do the ground work for his rehabilitation after this during this period so as to cushion the impact of the society on his injured personality on his final release from prison.

\section{Executive Discretion in Granting Parole}

In Indian Statutory Provision to release on furlough permit any prisoner who has been sentenced to a term of imprisonment of not less than five years and who has a record of good conduct in jail to be temporarily released for a period of three weeks after he has undergone imprisonment for a period of three years excluding remission, and for two weeks during each successive year of imprisonment thereafter, subject to certain conditions, limitations and just exceptions.

Release on furlough is not dependent upon the existence of any specific grounds, unlike temporary release on parole. The furlough power recognizes that a sullen and furlong prisoner cut off from the family and society for a long period is prone to make a more dangerous criminal and that such intermittent bout of temporary release from incarceration.

\section{Judicial Attitude}

The Courts in India have generally favoured the view that the prisoners who have been incarcerated or kept in prison without trial for a long time should be released on parole to maintain unity of family. In Babulal Das v State of West Bengal case [16] Hon'ble Mr. Justice Krishna Iyer of the Supreme Court though in the context of the preventive detention observed about the need for parole thus: "It is fair that persons kept incarcerated and embittened without trial should be given some chance to reform themselves by reasonable recourse to parole power under Section 15 of the Maintenance of Internal Security Act 1971".

In Samir Chatterjee v. State of West Benga1 [17] the Supreme Court, however, set aside the order of the Calcutta High Court releasing on parole a person detained under Section 3(1) of Maintenance of Internal Security Order and disfavoured the observation that long term preventive detention can be self defeating and criminally counterproductive. In Gurdeep Bagga vs Delhi

16 AIR 1975 SC606.

17 AIR 1975 SC1165.
Administration [18] a petition by life convict for parole on ground of illness of mother was rejected by the High Court on the ground that the petitioner was earlier continuously on parole for more than two years and that he had two elder sisters to look- after his ailing mother. However, the Supreme Court taking a lenient view recommended annual leave for him to maintain unity of family.

In Veeram Chaneni Raghvendra v. State of Andhra Pradesh [19] the Supreme Court ruled that release on parole and suspension of sentence during pendency of appeal in Supreme Court is liable to be struck down being ultra vires the statutory powers of the State Government. In Kesar Singh v. State of Himachal Pradesh [20] High Court laid down that the exercise of power of releasing a prisoner on parole or furlough must not be looked upon as an act of charity, compassion or clemency but as an act in the discharge of a legal duty required to be performed upon the fulfillment of the prescribed conditions to effectuate a salutary purpose.

In another decision it was pointed out that an apprehended breach of peace or the possibility of the prisoner committing a heinous crime during the parole period, without anything more, would constitute a law and order problem. These factors cannot be taken into account as factors subverting public order and would not be grounds to reject temporary release of prisoners.

In Charanjit Lal v. State the Delhi [21] High Court pointed out that remission by way of reward or otherwise cannot cut down the sentence to less than a minimum period of fourteen years. However, that does not mean that even a life convict falling within the ambit of Section 433A cannot be set free on parole or furlough during his sentence of imprisonment. There is no reason when even the life convicts who are hit by the mischief of Section 433A, be not released off and either on parole or on furlough subject, of course, to their undergoing atleast 14 years of actual imprisonment. The concept of constructive imprisonment while they are on parole on furlough does not enter into Section 433A even remotely.

\section{Nature of the Period of Parole}

When a convicted person on parole is arrested for another offence and put in jail, whether he is entitled for set off of his period of detention under Section 428 Cr.P.C. In Onkar Singh v. Police Officers [22] the High Court held that

181987 Cr.L.J 1419.

191985 Cr.L.J 1009.

201985 Cr.L.J $1202-1205$.

211985 Cr.L.J 1541.

221979 Cr.L.J 1098. 
he was entitled to count this period in jail against the sentence he has already undergone. In Faquir Singh vs State of Punjab [23] the vital point for consideration was whether the time spent by a prisoner on parole is or is not to be included towards total period of sentence of imprisonment. The petitioner in this case was sentenced to imprisonment for life. He sought his release on the ground that he has actually undergone Six years imprisonment inside the jail including the period in which he was on parole. But the authorities did not consider this on the ground that the period on parole by the prisoner cannot be counted as the period of actual imprisonment.

But the Punjab and Haryana High Court following spent on parole by a prisoner can legitimately be included in the period of imprisonment undergone by him and as such it has to be so considered while deciding his premature release case. Thus, the view taken by the Supreme Court is that the time spent on parole is part of imprisonment because it is a licensed release and the prisoner released on parole is not a free agent.

In Veramchaneni Raghvendra Rao v Government of Andhra Pradesh [24] the Government released persons sentenced to life imprisonment on parole on flimsy grounds such as financial problems, illness of relatives etc. The allegation in the writ. -petition was that these convicted persons belonged to some political parties and it was as a result of political pressure that these persons were released on parole when their appeal was pending before the appellate court.

\section{CONCLUSION}

\section{Need for a Policy}

Rehabilitation requires a guided return to the responsibilities of living in the free community. It is in this content that a parole system appears logical and necessary. A parole system cannot operate by itself but presupposes a prison or reformatory. Parole is not a mere method of reliving pressure of the prison population. It is the final step in the adjustment of the incarcerated offender to free society. It is part and parcel of a method of treatment which begins with incarceration in an institution [25].

It is preceded in the institution by successful steps in education for a trade and free social life, with discipline gradually released as the prisoner shows correction of his behaviour. Thus it can be seen that parole cannot be ignored. It is as half way house between outside prison and it facilitates the prisoner

231988 Cr.L.J 474.

241985 Cr.L.J 1009.

25 Thomson Douglas, "Prisons, Prisoners and Parole", West Thomson Reuters publications, 2013, p. 325. world. It serves to adjust. It is an effective measure as of safety and treatment reaction to crime by affording a series of opportunities to the parolee to prepare himself for an upright life in Society.

It is generally accepted that the efficiency of parole administration is greatly hampered due to undue Political and Executive pressure. In the result many undesirable prisoners procure their release on parole and the object of it is completely defeated many a times. A definite Judicial Policy is needed in matters of parole and the executive functions performed should be subjected to Judicial Review. Developed and Advanced Countries like USA and UK have established machinery where Judiciary has an effective role to play. In India the position is not the same. It is high time that our Legislatures should make necessary changes to strengthen our Criminal Justice System. 